\title{
Main Drivers of the Evolution of Management Accounting Concept in Russia: Global Ambitions vs. Local Way
}

Pavel Lebedev

IEDC Bled School of Management, Slovenia

p.lebedev@inbox.ru

This paper examines the main drivers that initially shaped and are currently influencing the understanding and development of management accounting in Russia, focusing on the specific roles of various stakeholders and institutions. In this research, the author adopted a grounded theory perspective. Data collection was based on archival methods with interpretive approach to the analysis. At the initial stage a thematic model of narrative analysis was applied, followed by an intensive multi-stages coding process at a subsequent phase of the study. The findings, including an emerged theoretical proposition, provide exploratory and explanatory views on the development and current state of management accounting in Russia. The obtained results suggest, that while management accounting in Russia is still an emerging concept, the influence of external factors represented by various stakeholders and institutions on the development of management accounting in Russia has been spontaneous, characterized by a lack of leadership, and unsustainable, driven by ignorance, opportunism, and self-interest of main actors.

Key Words: management accounting, emerging markets, market institutions

JEL Classification: M40, L2O

https://doi.org/10.26493/1854-6935.17.289-316

\section{Introduction}

Traditionally, most of the research in the area of management accounting and control was conducted in the Us, whereas it is only during the last decades it started to spread across continents with more papers published by authors from Europe to Australia (Bredmar 2011; Shields 1998). As English language is a dominating means of professional communications in financial and accountancy profession, most of the research in the area of management accounting and control has been, and still is, conducted in the Anglo-Saxon environment or, at least, is highly influenced by it. 
Historically, it is difficult to find information about management accounting practices in the countries other than the main global economic powers. Limited ability of many researchers to read about management accounting in languages other than English or, just on the contrary, one's native language hinders the understanding of the dynamics of changes that are occurring in a nation's (and global) management accounting practices, including the extent of changes in management accounting practice terminology, techniques, purposes of techniques, and styles of how techniques are used (Shields 1998). Thus, the lack of information regarding the development of management accounting in other countries, beyond the mainstream scope, creates a significant knowledge gap and limits our opportunities to learn and understand the dynamics of the profession.

Context-specific studies in management accounting contribute to close the abovementioned gaps. Research on emerging economies and dynamically changing environments fosters the inclusion of these countries into the global agenda, which is equally important for them and for their partners in the developed world. Such studies could effectively complement the existing body of knowledge by providing a perspective on the development of management accounting occurring beyond well and long-established paradigms of Anglo-Saxon management accounting and the 'controlling,' as it is often being referred to in Germanspeaking countries.

Since the collapse of the communist system, a market economy has evolved in Russia, which provided a competitive setting for Russian companies and a need for innovation and effective strategies (Chenhall, Kallunki, and Silvola 2011). While the country is a global energy and natural resource player as well as a member of the G2O economic powers, it has not been given as much attention as B RIC nations such as India and China in either academic research or the popular business press. The modest stream of existing research has mainly focused on dominating companies in the economy - natural resource-based companies and industries (Puffer and McCarthy 2011). At a global level, there are only a few attempts to look systematically into dynamics and scope of management accounting. Some studies only have a local outlook, meaning that they are never disseminated beyond national boundaries since most of them do not comply with internationally acceptable standards of academic work and Russian is their only working language.

The transition to a model of a developing economy in Russia after the 
collapse of the Soviet Union has led to the need to build and implement new systems and institutions that operate on the basis of market mechanisms in all social and economic areas. These processes experienced many hardships and still are far from their completion. The development and implementation of management accounting - a key element of business infrastructure - had an especially thorny path. Although Russia in general is adopting western-styled business practices, commercial, legal and accounting systems, as well as approaches to management and strategy, and formal management accounting controls, however, while western-based control practices are being integrated into routines of Russian firms, the application of contemporary practices continues to be limited (Chenhall, Kallunki, and Silvola 2011).

In a market-driven economy, management accounting lies in the very heart of business. It constitutes a core part of decision-supporting infrastructure and, by extension, is a vital part of the market mechanism. However, in Russia management accounting is still an emerging concept, and only recently has the debate within the profession become more inclusive of global topics (Lebedev 2014). An assessment of the gaps between the actual situation and the idealistic 'best-practice' vision and investigation of the underlying factors of these gaps leads to an informed understanding of the current and prospective dynamics of management accounting in a certain context. This informs the reasons for this study and justifies the effort.

While the modern nature of management accounting and its evolution are discussed in other sources, ${ }^{1}$ this paper looks into the factors which drive the dynamics of the phenomenon and determine its development with a focus on emerging economies as exemplified by Russia. It attempts to investigate how the main drivers which determine the development of management accounting, namely the key stakeholders and institutions, initially shaped and are currently influencing the evolution of the concept of management accounting in Russia, focusing on the post-Soviet period, when the country started its transition towards market economy.

This is a qualitative study. It follows an interpretive approach with an aim to develop grounded theory. The interpretive research genre in management accounting has truly come of age, and the ongoing discussion about it affirms the broad scope of what currently counts as 'good practice' for such methodology (Lukka and Modell 2010). The interpretive approach accounts for the social nature and the contextual peculiarities of management accounting. Interpretive theories aim to understand mean- 
ings and actions and how people construct them. Interpretive theories are helpful for several reasons. First, they help conceptualize the studied phenomenon to understand it in abstract terms. Second, they help articulate theoretical claims pertaining to scope, depth, power, and relevance of a given analysis. Third, they help acknowledge subjectivity in theorizing and hence recognize the role of experience, standpoints, and interactions, including one's own standpoint. Finally, they offer an imaginative theoretical interpretation that makes sense of the studied phenomenon (Charmaz 2014).

Qualitative research and interpretive approaches may produce especially fruitful results and contributions if applied in the context of dynamically changing environments. As directly prescribed by Kasanen, Lukka, and Siitonen (1993), researchers may consider the constructive approach when management accounting looks for its identity as a respectable discipline.

The rest of the paper is organized as follows. The next section addresses the research question and briefly illustrates the methodology. The subsequent section presents the findings, which provide an exploratory perspective on the role of various factors and their influence on the development of management accounting in Russia. The section 'Emerging theory' offers a theoretical proposition of explanatory nature based on the exploratory findings from the study, followed by a 'Conclusion' section containing final remarks on the research.

\section{Research Framework}

RESEARCH QUESTION

The research focuses on the post-Soviet period of modern Russia, when the country started its transition towards market economy. It constitutes a founding and integral stage of the bigger research project conducted by the author. The current study shapes and informs the subsequent investigation efforts. Figure 1 presents the overall research design framework.

This study mainly addresses the question: 'How the main drivers which determine the development of management accounting initially shaped and are currently influencing the evolution of the concept of management accounting in Russia?', forming at the same time a basis and contributing to the research on the questions 'How did the management accounting concept in Russia evolve and develop?' and 'What is the current understanding of management accounting in Russia.' 


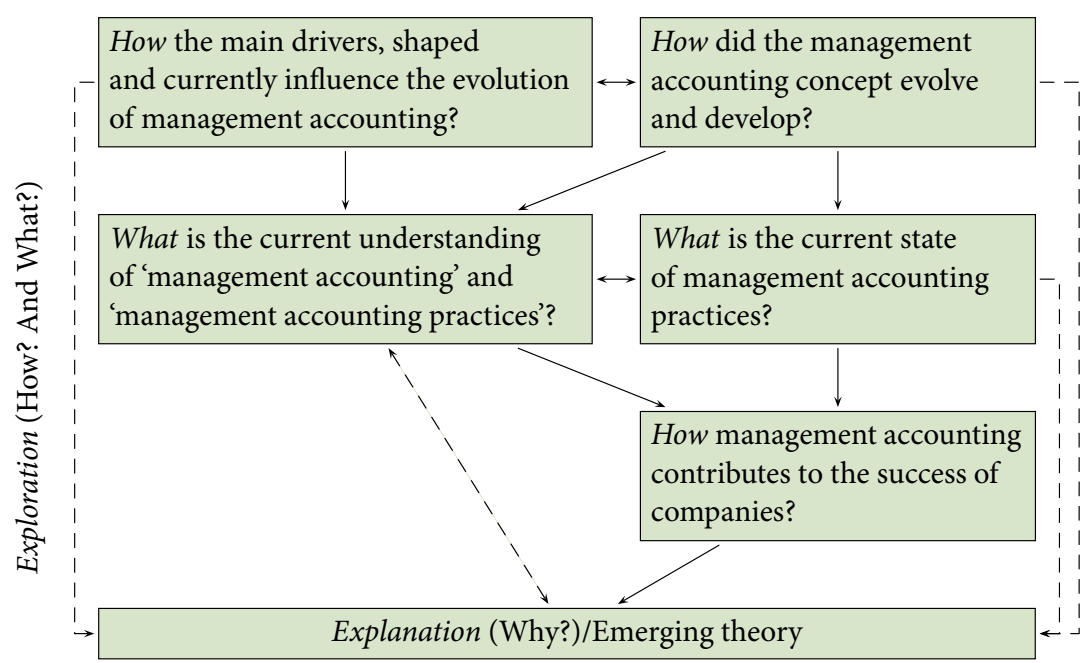

FIGURE 1 Overall Research Design Framework

\begin{tabular}{|c|c|c|}
\hline \multicolumn{3}{|c|}{ Historical studies } \\
\hline \multicolumn{3}{|c|}{ Archival research } \\
\hline $\begin{array}{c}\text { Literature-based } \\
\text { data }\end{array}$ & $\begin{array}{l}\text { Web-based } \\
\text { data }\end{array}$ & $\begin{array}{c}\text { Personal notes } \\
\text { (field notes/reminiscences) }\end{array}$ \\
\hline \multicolumn{3}{|c|}{ Interpretative approach/intuitive style } \\
\hline \multicolumn{3}{|c|}{ Thematic analysis model of narrative analysis } \\
\hline
\end{tabular}

FIGURE 2 Research Design Summary

\section{METHOD}

This is a historical study and is based on archival methods. The author obtained evidence from sources varying from related literature to personal field notes, reflections, observations, and experiences he gained in more than twenty years as a consultant and educator in the field of management accounting. The analysis of this study follows an intuitive style of an interpretive approach. The author applied a thematic model of narrative analysis of evidence (Lebedev 2019e). A summary of the research design is presented in figure 2, which is followed by details covered further in the related subsections.

The section 'Emerging theory' presents an excerpt from the working documentation of the coding process. It contains the summary of the higher level codes and categories which form the grounds for theoreti- 
TABLE 1 PEST Analysis for the Development of the Concept of Management Accounting

\begin{tabular}{ll}
\hline PEST groups of factors & Bhimani's factors \\
\hline Political & Government intervention and regulation. \\
\hline Economic & $\begin{array}{l}\text { Transfer of management accounting ideas and practices } \\
\text { across national boundaries by multinational companies. }\end{array}$ \\
\hline Social & Academics \\
& Education of students and employees \\
& Professional associations \\
& Consultants \\
\hline Technological & Technology \\
\hline
\end{tabular}

NOTES Base on Bhimani’s (1996) model.

cal explanations. The author used Bhimani's (1996) model of the seven factors that influence management accounting practices in European nations as a framework for structuring the research project. These factors include the influence of academics, education of students and employees, government intervention and regulation, the influence of professional associations, consultants, and technology, and transfer of management accounting ideas and practices across national boundaries by multinational companies. This presents an appropriate fit with a PEST model of external analysis - the most commonly used approach for considering the external business environment across the structure of political, economic, social, and technological factors (table 1). The internal analysis of the development of management accounting in Russia - a perspective from inside of companies - is covered in other studies (Lebedev 2018; 2019d).

Bhimani applied the model in his research of management accounting in 11 European countries and used it 'to provide a historical perspective on management accounting research and practice in their country, complemented by a discussion of salient raisons dêtres for the present practice and thought in the field' (cited by Shields 1998, 503). Table 2 presents a summary of the factors Bhimani applied and their directions of influence on management accounting practices.

\section{Findings and Discussion}

SUMMARY OF THE FINDINGS

Table 3 summarises the research findings. The Table contains factors (column 1), the extent to which each factor initially shaped the concept of management accounting (column 2), and the estimate of current influ- 
TA B LE 2 Bhimani's Seven Factors that Shape and Influence Management Accounting

\begin{tabular}{ll}
\hline Factors & Direction of influence \\
\hline Academics & $\begin{array}{l}\text { Their writings influence debate and practice (e.g., whether } \\
\text { full or variable costing should be used, relevant costs for } \\
\text { decisions, and, in some countries, 'champion' particular prac- } \\
\text { tices). }\end{array}$ \\
\hline $\begin{array}{l}\text { Education of students } \\
\text { and employees }\end{array}$ & $\begin{array}{l}\text { Education develops particular views about management } \\
\text { accounting, including the influence some textbooks and } \\
\text { teaching cases have on the development and diffusion of } \\
\text { management accounting practices. }\end{array}$ \\
\hline $\begin{array}{l}\text { Government interven- } \\
\text { tion and regulation }\end{array}$ & $\begin{array}{l}\text { For example, to control cost-based pricing and profits to } \\
\text { ensure a desired type and level of competition, particularly } \\
\text { when there were supply-demand imbalances in a national } \\
\text { economy, and, during World War I and World War II, to } \\
\text { ration resources and reduce war profiteering. }\end{array}$ \\
\hline $\begin{array}{l}\text { Professional associa- } \\
\text { tions }\end{array}$ & $\begin{array}{l}\text { Advocating particular management accounting practices and } \\
\text { best-practices. }\end{array}$ \\
\hline Consultants & $\begin{array}{l}\text { Advocating particular management accounting practices } \\
\text { and/or help firms design and implement practices. }\end{array}$ \\
\hline $\begin{array}{l}\text { Transfer of manage- } \\
\text { ment accounting ideas } \\
\text { and practices across } \\
\text { national boundaries }\end{array}$ & $\begin{array}{l}\text { The transfer occurs by academics, education, consultants, } \\
\text { and multinational businesses in a process of their activities. } \\
\text { which allows more information to be collected, processed, } \\
\text { and communicated, in a cheaper and quicker way. }\end{array}$ \\
\hline
\end{tabular}

NOTES Adapted from Shields 1998.

ence of each factor ${ }^{2}$ (column 3). The subsequent sections offer an indepth discussion of each factor.

THE ROLE OF ACADEMICS: 'THERE IS NO SEX IN USSR'3

In this study, the factor 'The role of academics' includes both the domains of research and teaching at academic programs, such as graduate programs. Professional development programs and business education are covered under the factor 'Education.'

The academic community influences the development of a profession through research, publications, debate, and practice. Good practices admit the importance of a right mix of excellence and relevance in research and teaching to ensure the desired outcomes for the stakeholders of the educational process (Abel et al. 2018). 
TA B LE 3 How Factors Initially Shaped and Are Currently Influencing Management Accounting in Russia

\begin{tabular}{lll}
\hline Factors & Initially shaped & Currently influence \\
\hline Academics & Insignificant & Moderate \\
Education & Moderate & Moderate \\
Government intervention & Insignificant & Insignificant \\
and regulation & \\
Professional associations & Insignificant & Insignificant \\
Consultants & Significant & Significant \\
$\begin{array}{l}\text { Technology } \\
\text { Transfer of practices by } \\
\text { academics, education, con- } \\
\text { sultants, and multinational } \\
\text { businesses across national } \\
\text { boundaries. }\end{array}$ & Moderate & Moderate \\
\hline
\end{tabular}

NOTES Adapted from Lebedev 2014.

Traditionally strong in natural sciences, Russian academia dramatically falls behind in social and economic sciences, having been influenced by the ideology of Marxism-Leninism for almost a century. The inherited Soviet practices of teaching and research were far both from relevance to the stakeholders' needs and aspirations (including students, employers, and society) and from excellence. The context of the transition time was characterised by lack of professionalism, lack of experience and understanding of a market economy, lack of financing, low status of education as opposed to the newly emerging rich class, whose representatives promptly created wealth without having any education at all. Hence, no surprise that, challenged with a task to start overnight teaching the concepts of the market economy, the old generation of academia failed - not only individual instructors, but all the system performed weakly.

Thus, during the first decade of transition (the period 1990-2000), the academic community did not play any significant role in the development of management accounting in Russia. Most instructors in educational institutions remained the bearers of the old Soviet approaches and traditions, no educational and methodological infrastructure were available in the form of modern technologies of teaching, relevant textbooks, research findings and developments; no connection to practice existed. The following statement summarises a common attitude towards the challenges the new realities brought, and a common lack of understanding of what 
management accounting is and why it is needed (Dean of a leading Russian university, interview by the author, April 24, 2010):

Why do we need this 'management accounting' at all? Who is going to teach it and how? You know, that there is only one professor at our department who has ever been there [abroad]. And even he doesn't understand what it is about, at least it seems so. And look at all these old ladies in our department. They will never cope! I wish they [the Government] would never push the accounting reform any further.

In spite of the fact that educational institutions had started to gradually include the course 'Management accounting' into the curriculum (in some institutions and universities it was named 'Controlling'), its content often did not have a direct connection with similar subjects in Western educational institutions. Most of the contents of 'Management accounting' courses were devoted solely to production costing; moreover, they did not cover more advanced topics, even in the domain of costing.

The situation slightly changed during the subsequent decades, which has led to some moderate influence of academia. Increasing exposure to the good international practices and efforts of the state to increase the competitiveness of educational system had some positive effects on the content of academic conversations.

In May 2013, in accordance with Presidential Decree of the Russian Federation N. 599 'On measures to realize state policy in the sphere of education and science,' a Russian Academic Excellence Project 5-100 was launched. It was intended to last for eight years and proclaimed such goals as maximizing the competitive position of a group of leading Russian universities in the global research and education market, keeping up with the current pace of international development, internationalization in all spheres, development of infrastructure to recruit the best scientists, faculty, managers, and students, development of an outstanding academic reputation by conducting breakthrough research, and recruiting the world's leading scientists (Prezident Rossiyskoy Federatsii 2012). Although the achievements of the initial goals are controversial and modest, the project has boosted research and publications.

To date, most of the difficulties of the initial period of the transition have been successfully overcome. The substantial content of curricula in management accounting and controlling is in many ways consistent with the programs of Western universities. This allows to characterise the degree of influence of academic's current role as moderate, but a lack of 
connection between teaching and practice still often occurs. Therefore, many programs are perceived as purely academic and theoretical, and far from the real world experience.

\section{THE ROLE OF EDUCATION: 'MONEY MAKES THE WORLD GO ROUND' (OR 'WE'LL TEACH YOU WHATEVER YOU PAY US FOR')}

Over the entire transition period, the role of educational programs in the development of management accounting can be defined as moderate. Importantly, in this study the factor 'Education' covers professional development programs and business education (i.e., seminars, trainings, and educational courses conducted by new-generation business schools, corporate universities, and private educational providers), whereas the specifics of graduate programs are included in the factor 'The role of academics.'

The moderate influence of such programs is conditioned by the following groups of factors: teachers and instructors' relative professionalism, participants' interest and motivation, and 'advanced' profile of companies sending the participants for training, compared to the overall situation. Instructors teaching in the abovementioned educational institutions were, as a rule, representatives of consulting community, not of an academic environment. This allowed to adapt the content of the programs and made them more applied, and also to use up-to-date information and 'best-practice' experience.

The main customers of such educational programs were usually represented by the companies of the 'new era' (i.e., the companies that were created after the collapse of the Soviet Union and that share the values of corporate training). Accordingly, the participants of such programs were, as a rule, representatives of the most 'market-oriented' part of the economy. Indeed, they were the employees of these advanced companies, which, at an early stage of their functioning, understood the value personnel's training and development can convey for the business. Accordingly, these people were carriers of a certain cultural code which not only admitted, but also supported, in every possible way, various training and development practices.

The main outcome of the influence of education on the development of understanding of management accounting was an attempt to introduce the world-class thinking on management accounting, its approaches, and its tools, at least to a part of the local professional community. This ex- 
posure was not an easy exercise. Most of the content was perceived as something that would never work, given the 'specifics' of the national context. The 'specifics of our business' or the 'specifics of our context' are commonly used phrases in the Russian corporate environment, and often hide reluctance to make a try of anything new.

As business education was strongly commercialised, customer satisfaction became one of the concerns of educational providers. However, it was understood rather simplistically, without any reflections on the complex nature of the customer in business education. The most important was the immediate satisfaction of the participants of educational programs, as measured by questionnaires after the end of the course. Numerous attempts were made to provide some adaptation of the taught content to consider any possible 'specifics' and, thus, ensure high scores; however, it looked more like flirting with customers. It led to the increasing offer of various attractively named programs with doubtful quality and inferior content.

Briefly, the most important influence of the factor 'Education' was in that it activated some dynamics to thinking and rethinking of the essence of management accounting. The effect was similar to planting many seeds, some of which could later give birth to a plant of knowledge and understanding, while many others would not, depending on their own quality and quality of the soil.

THE ROLE OF GOVERNMENT INTERVENTION AND

REGULATION: 'WHAT MANAGEMENT ACCOUNTING?

PLEASE, DO NOT DISTURB.'

The influence of the government and its regulation on the development of management accounting, both in the early years of its formation and later on, were insignificant. The state was not able to see the benefits of management accounting, did not acknowledge its existence, and was not interested in it, having another agenda of the development of accounting in the country.

Traditionally, the role of the state is paramount in Russia. This is true, among other things, in the area of accounting regulation. As one of the most interested financial information users and of the most powerful stakeholders in the relations of financial information flows across the economy, the state fully used its position to push the accounting nationwide towards the direction of tax-accounting and taxation control. This was especially evident during the first decade of the transition period, 
when no distinctions between financial and tax accounting existed and the statutory accounting was harmonized with tax accounting and control. Formally, the situation changed with the adoption of a tax code in the period 1998-2000, which meant that what was not included in its scope was intended to be financial accounting (Gosudarstvennaia Duma Rossiiskoy Federatsii 1998). However, while tax accounting was perceived as a burden with which a company was obliged to comply (sometimes just to a certain extent), financial accounting was perceived as an unnecessary burden. At that time, most people in the companies did not have a culture of working with numbers, neither the skills of financial evaluation and analysis. There was a lack of demand for financial information from managers, who, instead, could have used it to make better decisions. They preferred to make them opportunistically and intuitively. Further, there was no demand for management accounting, because 'accounting' was the key burdensome word.

During the subsequent years, one single attempt to incorporate the concept of management accounting into the legislation was made through the inclusion of the subsection of accounts which deemed to serve the needs of management accounting into the official chart of accounts (Ministerstvo Finansov Rossiyskoy Federatsii 200o). This was the only artefact, which, in the opinion of the developers of the document, should have supported the process of costs analysis. It was provided that, 'for management accounting purposes, a company may open accounts in the section 30 for each cost element,' and a handful of accounts (namely 10 accounts only from 30 to 39 , with some of them blank) was offered. This confirms a very narrow view of management accounting, and its identification solely with cost and production accounting, even in cases when some understanding of it existed and the overall rejection of the phenomenon. All was on behalf of the state. Last, but not least, it went practically unnoticed by the accounting community.

THE ROLE OF PROFESSIONAL ASSOCIATIONS:

SO MUCH TO DO, SO LITTLE TIME

Professional associations are organisations serving the interests of a profession, the individuals engaged in the profession, and the public interest (see https://en.wikipedia.org/wiki/Professional_association). They shape the professions by promoting and advocating best practices and approaches to professional activities, and by providing professional education, development, and certifications. These state-of-the-art solutions are 
distilled through research, collaboration, and extended dialogue among stakeholders. An exemplary case is an alliance between the two most prestigious global associations: the American Institute of Certified Professional Accountants (AICPA) and the Chartered Institute of Management Accountants (CIMA), which in 2017 founded the Association of International Certified Professional Accountants, representing more than 650,000 members and students in 179 countries. Global management accounting principles these associations have developed and advocated guide the best practice and inform management accounting profession all over the world (The Chartered Institute of Management Accountants 2017).

Russian professional organisations in the field of accounting are limited in their number and in the number of their members. They are created on a different basis; they were not a good will of their members, but the result of personal goals and a political sophistication of their founders. They have neither sufficient resources, nor will to carry out research to generalise and promote best practices. Relationships within organisations are excessively politicized and built around the establishment of personal influence of organisational leaders. Membership in these organisations is perceived not as an act of goodwill, but as a transaction. Accordingly, members do not have any expectations regarding the support of the association for their professional activities. The transactional nature of the participation in such organisations assumes the deal: the members pay modest annual fees and formally participate in obligatory continuing professional development programs the associations provide (another stream of revenue), and receive in exchange the certifications they might need for compliance regulations. Thus, unfortunately, in Russia professional associations are viewed more as an element of compliance, rather than as a mutually enriching mechanism for communication between professionals who are united by common values. Only in rare instances, community members see themselves as a means of interaction, communication, and exchange of experience.

The case of the Institute of Professional Accountants of Russia (IPAR) is exemplary. The IPAR claims to be the largest professional accounting association in Russia (see https://www.ipbr.org). However, finding an exact number of active members is tricky. On its website, the IPA R states that annually it provides educational programs to 70000 members. The operational and financial models of the organisation lack transparency. Dozens of organisations are in some way affiliated to the IPAR, as the 
Trade Register of Russia evidences, and most of them have a registered seat in various regions of Russia. As to the IPAR itself, as of June 16, 2019, it had six founders: three educational institutions, a state-owned publishing company, and a research institute under the Ministry of Finance. This research institute ceased to exist as a separate entity in 2006, and was merged with another educational institution and another professional association which had been inactive for years and was finally liquidated on June $7,2019^{4}$ (Federal'naia nalogovaia sluzhba Rossii 2019). Obviously, these entities are not about the professional community; rather, they represent a strong and specific business case of legitimising the interests of a narrow circle of players who are able to exploit political and social capital to take an opportunity to talk on behalf of the profession.

In summary, during all the three decades this study considers, professional associations in Russia did not have any significant impact on the development of management accounting.

Importantly, the situation the author described is exclusively related to national professional associations; the role and influence of international professional associations acting in Russia, such as the Association of Chartered Certified Accountants (ACCA) or the Chartered Institute of Management Accountants (CIMA), as well as a number of others, are different and worth considering in a separate study. In general, given their prestigious reputation and high standards, they were serving a very narrow segment of companies and members, who conform or aim to conform to world-class practices.

THE ROLE OF CONSULTANTS: GO WEST (BUT NOT TOO FAR)

Consultants influence the development of management accounting by advising, implementing, and advocating certain management practices, promoting tools and concepts, and expressing respected expert opinion, which altogether are often regarded as a frame of reference. Their authority and credibility to do this are determined by accumulated skills and competences, and long-term toiling for the sake of clients and developing relationships, which assumes a huge investment of money, time, and effort.

In Russia, the development of consultancy as a profession, including consultancy in management accounting, followed a specific path, which resulted in a rather perverted form of outcomes, especially in the early years of the transitional economy, in the period 1990-2000. Indeed, at that time, due to the lack of balance of opinions, consultants were of- 
ten perceived as the only possible truth (not to mention the often doubtful quality of the advice given), but also as an evil, sometimes necessary, but mostly not. The underlying values of consultants' professional activity were far from the foundations of sustainability and serving the public well. They had a sharp commercial pragmatic focus and opportunist approach to conducting projects, with no fear of unrealistic promises to their clients.

In the first decade of the economic transition in Russia (1990-2000), there were three main streams of origination of the consultancy profession in the area of management accounting:

- Russian repatriates who had gained some exposure to Western practices (mainly in the United States) as students, postgraduate students, and trainees, for example. Such possibilities allowed to understand the borders were open and Russian citizens were able to travel abroad.

- Local consultants who emerged as a result of a booming demand for accountants and basic accountancy services, which were determined by the liberalisation of economy and the creation of a huge number of private enterprises. These consultants were mainly auditors acting as sole proprietors or they were founders of audit companies which offered consulting services in addition to core activities.

- Western consultants who were available through the numerous technical assistance programs reputable international organisations and institutions (e.g., World Bank, International Finance Corporation, European Bank for Reconstruction and Development, and European Commission's 'Technical Assistance to the Commonwealth of Independent States' programme) ran at that time.

Global international consultancies (e.g., The Boston Consulting Group, McKinsey \& Company, PricewaterhouseCoopers, and Deloitte) exclusively advised the government and big international companies. These segments represented a very narrow and closed part of the economic landscape, without any significant influence beyond the 'elite' boundaries.

Table 4 summarises the specifics of the main streams of the origination of consultancy in management accounting and their influence on management accounting in Russia.

Russian repatriates represented the most influential group of consultants, as they offered the most practical solutions compared to the 'nice- 
TABLE 4 Main Streams of Origination of Consulting Practices in Management Accounting in Russia

\begin{tabular}{llll}
\hline Category & Russian repatriates & Local consultants & Global consultants \\
\hline Origin & $\begin{array}{l}\text { Local, repatriated } \\
\text { after some exposure } \\
\text { to global settings. }\end{array}$ & Local & Global \\
\hline $\begin{array}{l}\text { Source of experience } \\
\text { and expertise }\end{array}$ & Mainly us & Russia & $\begin{array}{l}\text { Mainly } \\
\text { Us/Germany/Other } \\
\text { European countries. }\end{array}$ \\
\hline $\begin{array}{l}\text { Type of services } \\
\text { rendered in Russia }\end{array}$ & $\begin{array}{l}\text { Balanced mix of } \\
\text { trainings and con- } \\
\text { sulting projects. }\end{array}$ & $\begin{array}{l}\text { Mainly consulting } \\
\text { projects. }\end{array}$ & $\begin{array}{l}\text { Mainly trainings } \\
\text { and seminars. }\end{array}$ \\
\hline Content/Focus & Reporting & $\begin{array}{l}\text { Basic tools and } \\
\text { concepts, attempts } \\
\text { to address specific } \\
\text { clients' needs. }\end{array}$ & $\begin{array}{l}\text { Basic tools and } \\
\text { concepts. }\end{array}$ \\
& & & \\
\hline
\end{tabular}

to-have' storytelling of the global consultants or a handful of tailored solutions of local consultants. The focus on reporting the repatriate consultants' group chose was also successful from the point of view of expansion of their influence and their personal professional promotion. To a very great extent, it had determined the thorny 'path' of management accounting in Russia, as opposed to selecting a 'highway' of commonly accepted practices which the rest of the world wisely preferred. This specific understanding of management accounting consultants advocated assumed that management accounting was first and foremost responsible for the preparation of truthful financial statements in the interests of the owners of a company. Thus, consultants mainly contributed to the formation of a very specific understanding of management accounting as a superior accounting system in terms of quality of financial reports, compared to, for example, financial accounting. This manifested their main influence on the development of management accounting.

The abovementioned focus on reporting was meant to close the information gap which had been arising due to the imbalanced system of reporting that had been historically developed in the country during the first decade of the transition of economy. As the author noted above, the official accounting served mainly the interests of the state, primarily the interests of tax authorities. The lack of a culture of paying taxes, with a general reluctance to do it, and the absence of a culture and skills of using of any kind of financial reporting for decision-making contributed to 
make companies' owners and managers perceive and approach statutory and tax accounting as an evil or a burden.

According to consultants, managerial accounting was intended to be the solution that would allow preparing 'real' reports, presenting truly what was happening in the company, as opposed to the other perspectives financial and tax accounting provided. Hence, such terms as 'true balance,' 'real balance,' and 'true profit and loss statement' were often used in consulting companies' promotional materials and consultants' publications. Also, even more extreme cases occurred, as it was not unusual to see such advertisements as 'we will provide you with management accounting based on international financial reporting standards' (see https://www.specialist.ru/course/upmsfo; Zolotukhina 2015).

The second most popular theme consultants promoted was automation of management accounting. This is discussed in detail in the following section.

Briefly, the involvement of consultants in the development of management accounting nationwide was characterised by a pragmatic egoistic approach. It assumed a push selling strategy of whatever could be sold to the unsophisticated clients who were constantly looking for a magic pill and did not wish to make any additional effort or suffer any extra pain of organisational transformation or take their own responsibility for organisational change. It was a favourable context which accommodated any type of ploy, fake solutions, and promises never to be fulfilled. The case of a Management Accounting Council under the Ministry of Economic Development of Russia provides a relevant and typical picture.

The Management Accounting Council under the Ministry of Economic Development of Russia was created in 1999 as a successful lobbying initiative of several consulting companies, in fact qualifying for a definition of micro-business. The quasi status 'under the Ministry' does not assume any legitimate status, nor constituted the arrangement any formal part of the Ministry, nor assumed it any power to issue any legislative acts. The ploys of such kind are often-used vehicles in Russia to foster and legitimise initiatives of selected interested companies that try to gain some advantage from being close to the power.

It is and it was then very difficult to find any official information regarding the council. On the web page of the project (which has not been updated nor supported for more than a decade) which was affiliated to one of the founding companies of the council, a then-manager of this company, and a member of the council stated that the body 'consists of 
25 people, including representatives of enterprises, scientific and educational institutions, and consulting companies' (Gershun n.d.). The council proclaimed that it would: expand the range of enterprises that used the best management accounting mechanisms in their activities for making management decisions; stimulate the use of the best experience of foreign countries in the development of financial management systems and management accounting in the Russian context; develop basic methodological recommendations on the organisation and maintenance of management accounting in enterprises, taking into account Russian and foreign experience; explain to enterprises' management and owners the importance of management accounting; accelerate the process of forming a professional community; support the process of uniting professionals in the field of management accounting (Ibid.).

The most ambitious task the council tried to accomplish was an attempt to develop methodological recommendations on management accounting, which covered a range of topics such as goals and objectives of management accounting, management accounting tasks, main components of the management accounting system in an organisation, basics of management reporting, and requirements for management reporting organisations. In essence, the document presented a compilation of the basic concepts from textbooks, which were further simplified. It goes without saying that the document went unnoticed. However, what is worth pointing out is the shameless attempt to present it as a piece of legislation. Indeed, the document was prefaced by the following statement:

Approved by the Management Accounting Council under the Ministry of Economic Development of Russia. Recommended for use by Russian enterprises by the Management Accounting Council under the Ministry of Economic Development of Russia. Minutes of the meeting of April 22, 2002, n. 4. (Ekspertno-konsul'tativnyi sovet po voprosam upravlencheskogo ucheta pri Minekonomrazvitiia Rossii 2002).

Obviously, minutes of a meeting of an odd structure, approving summaries from international textbooks on management accounting, and recommending it for usage by Russian enterprises were not a normative act, and by no means it could be. Rather, it demonstrates the mindset, ambitions, and cynicism which informed many similar arrangements. 
TABLE 5 Characteristics of Various Types of Iт Solutions for Accounting in Russia Since the $1990 \mathrm{~s}$

\begin{tabular}{lllll}
\hline Category & $\begin{array}{l}\text { Mainstream } \\
\text { local }\end{array}$ & Other local & Compact global & Big global \\
\hline $\begin{array}{l}\text { Examples of IT } \\
\text { solutions }^{6}\end{array}$ & 1C & $\begin{array}{l}\text { Galaktika, Best, } \\
\text { Info-Bukhgalter }\end{array}$ & $\begin{array}{l}\text { Axapta, Hansa } \\
\text { Ansion, }\end{array}$ & $\begin{array}{l}\text { Oracle Finan- } \\
\text { cials, s A }\end{array}$ \\
\hline $\begin{array}{l}\text { Designed for a } \\
\text { company }\end{array}$ & Any size & $\begin{array}{l}\text { Small and mid- } \\
\text { sized }\end{array}$ & Mid-sized & Big \\
\hline $\begin{array}{l}\text { Availability of } \\
\text { consultants }\end{array}$ & Plenty & $\begin{array}{l}\text { Limited num- } \\
\text { ber }\end{array}$ & Few & Few \\
\hline $\begin{array}{l}\text { Cost of imple- } \\
\text { mentation }\end{array}$ & Low & Moderate & High & High \\
\hline $\begin{array}{l}\text { Chances of } \\
\text { successful im- } \\
\text { plementation }\end{array}$ & High & High/Medium & Low & Low \\
\hline \begin{tabular}{l} 
Selling strategy \\
\hline
\end{tabular} & Pull & Pull/Push & Push & Push \\
\hline
\end{tabular}

\section{THE ROLE OF TECHNOLOGY: 'WE ARE THE CHAMPIONS (OR AT LEAST WE TRY OUR BEST)'}

Technology and the computerisation of accounting systems allow more information to be collected, processed, and communicated, in a cheaper and quicker way. Advanced solutions as manufacturing resource planning (MRP), enterprise resource planning (ERP), and business intelligence (в І) systems foster the process of analysis and decision-making, thus potentially advancing management accounting systems and creating competitive advantages to a company. Besides, the implementation of technology usually requires rethinking and remodelling of business processes, which, in turn, direct the effort towards the revision of the company's strategic agenda. All these elements require external (i.e., the consultants) and internal (i.e., updated skills and competences of the staff) competences. Thus, it could be reasonably assumed that a successful implementation of technology, or even an attempt to do so, could move the company to the right side along the maturity level continuum of management accounting. ${ }^{5}$

The booming market for computerisation and automation of accounting in Russia had a moderate influence on the development of accounting during all the three decades of the transition of economy, since the 199os. This influence was determined by the types of solutions which were available on the market (table 5). 
1C is the most popular accounting software in Russia. Founded in 1991, the 1C company has specialised in development, distribution, publishing, and support of mass-market software, as of 2019 having 8000 dealers from 600 cities and about 7500 teams constituting the 1C: Franchising partner network (see http://1c.ru/eng/title.htm). The scale of the company, its network of partners, reasonable prices, country-wide availability of support, and easiness of implementation ensured high penetration of this software. The overall influence of the implementation projects on the development of management accounting was an introduction to some very basic concepts of management accounting $1 \mathrm{C}$ consultants provided to the companies in order to facilitate such projects. However, in many cases, the consultants themselves had very modest understanding of the subject.

The introduction to the Russian market of IT products such as SAP, Axapta, and other similar world-class systems also had a certain impact on the practice of management accounting. As a rule, the company's suppliers offered comprehensive solutions and had appropriate consulting units. Employees of such units were consultants whose profile is described above and is mainly corresponding to those of Russian repatriates. The implementation solutions such companies offered were expensive and had a very broad scope, including business diagnostics, business processes analysis and reengineering, and HR consulting, for example. Being unable to offer solutions in the context of 'as is,' they advocated a large-scale change, which constituted a huge portion of the overall budget, as well. Needless to say, the results of such projects were questionable, if any, and took years of interaction between companies and consultants. However, they have resulted in some knowledge and understanding among the involved employees. This understanding was limited and, in most cases, far from being practical, but its positive influence was serving mainly as a multiplier of awareness.

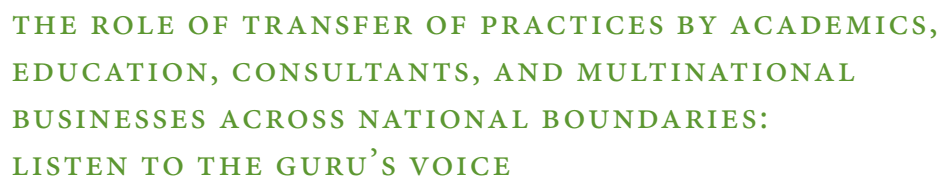

International companies have had a certain impact on the development of managerial accounting and its understanding in Russia. When these companies accessed the Russian market, they brought with them management technologies. This fully affected the practices of management 
accounting the local companies under influence employed. The transfer of technologies by such international companies was usually carried out as follows. First, foreign employees arrived and implemented their parent company's internal technologies and practices, with minimal differences, trying to take into account the Russian context (including Russian legislation and regulations). These employees occupied top managerial posts, and they also managed key functional areas. Russian specialists were invited to take on roles in the middle management, if they had foreign practical experience or completed foreign educational programs. The role of ordinary staff was reserved to local employees. This created the conditions for the realisation of the multiplier effect, when the concepts which were introduced from abroad were taken as a sample. The unconditional authority of international companies, which was especially observed in the first decade of the development of management accounting in Russia, led to the fact that all the management concepts that went beyond the boundaries of these companies and became known to others were at once legitimised and considered to be the only true ones.

\section{Emerging Theory}

This study constitutes to a part of bigger investigation of the development of management accounting in Russia in the post-Soviet era and it focuses on the external drivers which formed and informed the understanding of the concept of management accounting (Lebedev 2019b). Having a qualitative interpretive nature, this study forms a basis for grounded theoretical conceptualisation regarding the development of management accounting in Russia.

Corbin and Strauss (1990) provide a systematic overview of canons and procedures of the grounded theory approach. They include the following:

- data collection and analysis are interrelated processes;

- coding;

- concepts are the basic units of analysis;

- categories must be developed and related;

- sampling in grounded theory proceeds on theoretical grounds;

- analysis makes use of constant comparisons;

- patterns and variations must be accounted for;

- process must be built into the theory;

- writing theoretical memos is an integral part of doing grounded theory; 
- hypotheses about relationships among categories are developed and verified as much as possible during the research process;

- a grounded theorist needs not to work alone;

- broader structural conditions must be brought into the analysis, however microscopic in focus is research.

A classic set of analytic moves in qualitative analysis follows the next sequence:

- assigning codes or themes to a set of field notes, interview transcripts, or documents;

- sorting and sifting through these coded materials to identify similar phrases, relationships between variables, patterns, themes, categories, distinct differences between subgroups, and common sequences;

- isolating these patterns and processes, and commonalities and differences, and taking them out to the field in the next wave of data collection;

- noting reflections or other remarks in jottings, journals, and analytic memos;

- gradually elaborating a small set of assertions, propositions, and generalizations that cover the consistencies discerned in the database;

- comparing those generalizations with a formalized body of knowledge in the form of constructs or theories (Miles, Huberman, and Saldaña 2014).

Evidently, in the heart of qualitative analysis lies coding. Codes are labels that assign symbolic meaning to the descriptive inferential information compiled during a study; they are attached to data 'chunks' of varying size and can take the form of a straightforward, descriptive label or a more evocative and complex one (e.g., a metaphor) (Miles, Huberman, and Saldaña 2014, 71).

Over the course of the project, the author applied the following coding techniques. At an initial phase of coding a deductive approach was taken, based on a preliminary developed provisional start list of codes. The list was based on the prior work, knowledge, and experience, on the conceptual framework for the research, list of research questions and the preunderstanding brought into the study from the previous phases of the project. The start list consisted of fifty preliminary codes. Two exploratory methods, holistic and provisional coding, supported this pro- 
TAB LE 6 Theory Building: An Excerpt from the Working Documentation of the Coding Process

\begin{tabular}{|c|c|c|}
\hline Codes & Categories & Concept \\
\hline $\begin{array}{l}\text { Soviet traditions in academia } \\
\text { Poor infrastructure for education } \\
\text { Nihilism } \\
\text { Scepticism } \\
\text { Firm belief in own obsolete knowledge }\end{array}$ & Ignorance & \multirow{4}{*}{$\begin{array}{l}\text { The influence of } \\
\text { external factors on the } \\
\text { development of } \\
\text { management } \\
\text { accounting in Russia } \\
\text { has been spontaneous } \\
\text { (lack of leadership) and } \\
\text { unsustainable (driven } \\
\text { by ignorance, } \\
\text { opportunism, and } \\
\text { self-interest of main } \\
\text { actors). }\end{array}$} \\
\hline $\begin{array}{l}\text { Newly emerging informational needs } \\
\text { Gap between needs and outcomes of } \\
\text { management accounting } \\
\text { Unwillingness of companies to make efforts } \\
\text { Conservatism of decision makers } \\
\text { Fashion for foreign solutions } \\
\text { Expectations of a 'magic pill' }\end{array}$ & Opportunism & \\
\hline $\begin{array}{l}\text { Lack of professional community } \\
\text { Short-term orientation } \\
\text { Unsustainable consulting practices } \\
\text { Promises never to be fulfilled } \\
\text { Commercial focus } \\
\text { Cynicism }\end{array}$ & Self-interest & \\
\hline $\begin{array}{l}\text { Unwillingness to take responsibility } \\
\text { Unwillingness of companies to make efforts } \\
\text { Non-involvement of non-financial managers } \\
\text { Expectations of a 'magic pill' } \\
\text { Transactional approach to change } \\
\text { management }\end{array}$ & $\begin{array}{l}\text { Lack of } \\
\text { leadership }\end{array}$ & \\
\hline
\end{tabular}

cess by serving as its foundation, and it was enriched by In Vivo and evaluation coding techniques where appropriate. As noted by Miles, $\mathrm{Hu}$ berman, and Saldaña (2014), for all approaches to coding, several codes will change and develop as field experience continues. At the same time, other codes flourish and too many segments get the same code, thus creating the problem of bulk. These issues lead to inductive coding when other codes emerge progressively and some of the existing codes are being changed, amended, updated, and rearranged, which was exactly how the project developed.

Table 6 presents an excerpt from the working documentation of a coding process. It demonstrates the logic of arriving to theoretical conclusions. The constructivist grounded theory arose as an alternative to objectivism. Objectivist grounded theorists aim to conceptualize the data without taking an interpretive stance. For example, Glaser (2002) treats data 
as something separate from the researcher, which implies that data are untouched by the competent researcher's interpretations. However, constructivists study how and why participants construct meanings and actions in specific situations (Charmaz 2014). Theories try to answer questions by offering accounts for what and how a phenomenon happens and may aim to account for why it happened, and theorizing consists of the actions involved in constructing these accounts (Charmaz 2014). Saldaña (2013) with reference to Tavory and Timmermans (2014) and Gibson and Brown (2009) suggests that a social science theory has four main characteristics, as it is traditionally conceived:

- it predicts and controls action (through an if-then/when-then/since that's why logic);

- it accounts for variation in the empirical observations;

- it explains how and/or why something happens by stating its causes and outcomes;

- it provides insights and guidance for improving social life.

At the finalizing stage of the study the author developed a following theoretical proposition concerning the development of management accounting in Russia:

The influence of external factors on the development of management accounting in Russia has been spontaneous (lack of leadership) and unsustainable (driven by ignorance, opportunism, and self-interest of main actors).

This theoretical proposition explains the findings regarding the development of management accounting in Russia that the author explored throughout the project, and serves as the basis for further research, including the possibility of reframing and operationalizing it for future theory testing studies.

\section{Conclusion}

With a lack of similar contextual studies, going beyond traditional AngloSaxon scope of research in management accounting, this work makes a theoretical contribution by complementing existing related conversations in science and professional practice with an attempt to improve an understanding of the development of management accounting in Russia.

The study revealed that management accounting in Russia is still an emerging concept. It has gone a long route from its widely held understanding, which is somewhat equivalent to shadow accountancy in the 
9os to management reporting systems or a vague concept of the system of information collection, processing, and distribution for the support of management decisions. The role of main actors/stakeholders in the development of management accounting was in general insignificant. At an early stage of development of management accounting in Russia, it was primarily consultants who influenced and informed the concept, with an increasing role of academics and education, as well as cross-border information exchange during the last decade. The specific understanding of management accounting the first generation of consultants had brought in had significantly determined its 'own' way of development, which only currently is becoming more converged to the global understanding of the concept. The influence of external factors on the development of management accounting in Russia has been spontaneous, characterized by a lack of leadership and unsustainable, driven by ignorance, opportunism, and self-interest of main actors.

Practical implications also include the possibility to employ the results of the research to support decisions in the transformation of the financial function along its maturity continuum (both conducted internally by managers and/or with external support of consultants and advisors). This study could also be used as an educational content for programs in professional and business education.

Future research on the topic would be highly appreciated. It should focus on the immediate voice of business. It would be interesting to see primary evidence of management accounting development and its dynamics to understand the bigger picture and case studies to scrutinize the experiences of companies. Another important track could be advancing and reframing of the formulated theoretical proposition for the theory-testing studies and conducting such studies.

Research results could have been influenced by contextual nature and subjectivity of interpretative analysis, possible incompleteness and subjective selection of archival and field data, and limited resources for analysis and interpretation, given the huge scale of the project. The author considered these potential limitations as much as possible at the planning and design stages of the project, and continuously assessed them along the study.

\section{Notes}

1 Two suggested studies (Lebedev 2019a; 2019e) provide an outlook on the evolution of the role of management accounting, from transactions pro- 
cessing to financial leadership (2019a), and the evolution of a contextspecific understanding of management accounting concept in Russia (2019e).

2 The author selected and justified the scale in a progress of extensive coding procedures he applied at the stage of the data analysis.

3 'There is no sex in USSR' is a popular catchphrase and refers to the comments of Liudmila Ivanova. Ms. Ivanova's comments were aired on a perestroika-era TV Show, us-Soviet Space Bridge. An American asked about sex in the Soviet Union. Ms. Ivanova intended to say "There is no sex in the UsSR ... there is love," but the last words were cut off of the broadcast' (An American in Moscow 2010).

4 According to the Trade Register of Russia, there is another association with a similar name, registered by 8 physical persons on June 25,2009 . It has a different registration number; however, it is registered on the same business address.

5 Lebedev's (2019c) study of management accounting maturity level continuum provides a detailed discussion of the concept.

6 Examples of software do not reflect changes in brand names or brand ownerships which have occurred as a consequence of $\mathrm{M} \& \mathrm{~A}$ deals in IT industry.

\section{References}

An American in Moscow. 2010. 'There Was No Sex in ussR.' https:/usa -moscow.blogspot.com/2010/o4/there-was-no-sex-in-ussr.html

Abel, D., D. Purg, A. Braček Lali, and N. Kleynand. 2018. 'Manifesto: Changing the Course of Management Development; Combining Excellence with Relevance.' Report, Bled.

Bhimani, A., ed. 1996. Management Accounting: European Perspectives. Oxford: Oxford University Press.

Bredmar, K. 2011. 'Theoretical Foundations of the Concept of Management Control: A References Analysis.' International Journal of Management 28 (2): 412-27.

Charmaz, K. 2014. Constructing Grounded Theory. and edition. London: Sage.

Chenhall, R. H., J.-P. Kallunki, and H. Silvola. 2011. 'Exploring the Relationships between Strategy, Innovation, and Management Control.' Journal of Management Accounting Research 23 (1): 88-128.

Corbin, J. M., and A. Strauss. 1990. 'Grounded Theory Research: Procedures, Canons, and Evaluative Criteria.' Qualitative Sociology 13 (1): 321.

Ekspertno-konsul'tativnyi sovet po voprosam upravlencheskogo ucheta pri Minekonomrazvitiia Rossii. 2002. 'Metodicheskie rekomendatsii 
po organizatsii i vedeniiu upravlencheskogo ucheta.' https://www .twirpx.com/file/152176/

Federal'naia nalogovaia sluzhba Rossii. 2019. 'Predostavlenie svedenii iz EGRIUL/EGRIP.' https://egrul.nalog.ru/index.html

Gershun, A. n.d. 'Razvitiie upravlencheskogo ucheta v rossii i rol' Ekspertnokonsul'tativnogo soveta po upravlencheskomu uchetu pri Minekonomrazvitiya $\mathrm{RF}$.' http://consulting.ru/209ias2

Gibson, W., and A. Brown. 2009. Working with Qualitative Data. London: Sage.

Glaser, B. G. 2002. 'Constructivist Grounded Theory?' Forum: Qualitative Social Research 3 (3). http://dx.doi.org/10.17169/fqs-3.3.825

Gosudarstvennaia Duma Rossiiskoy Federatsii. 1998. Nalogovyi kodeks Rossiyskoi Federatsii: Chast' pervaia. Moscow: Gosudarstvennaya Duma Rossiyskoy Federatsii.

Kasanen, E., K. Lukka, and A. Siitonen. 1993. 'The Constructive Approach in Management Accounting Research.' Journal of Management Accounting Research 5:243-64.

Lebedev, P. 2014. 'Evolution of Management Accounting Concept in Russia: In a Search of Identity. Procedia: Social and Behavioral Sciences $156: 580-84$.

- 2018. 'Management Accounting in Russian Mid-Sized Companies: Results of an Extended Survey-Based Study'. In Proceedings of the 17th International Scientific Conference Globalization and Its SocioEconomic Consequences, 1196-203. Rajecke Toplice: University of Zilina. - 2019a. 'Defining Financial Leadership: Reflections on Current Conversations about a Changing Role of Management Accounting.' Paper presented at the 6th International Multidisciplinary Scientific Conference on Social Sciences \& Arts SGEM 2019, Vienna.

- 2019b. 'Management Accounting in Russian Mid-sized Private Companies: A Report on a 2014-2019 Research Journey'. Paper presented at the 6th sws International Scientific Conference on Social Sciences 2019, Albena.

- 2019c. 'Management Accounting Maturity Levels Continuum Model: A Conceptual Framework.' European Journal of Economics and Business Studies 5 (1): 24-36.

- 2019d. 'Management Accounting Practices in Mid-Sized Companies in Emerging Economies: An Evidence from Russia.' In Knowledge - Economy - Society: Challenges for Contemporary Economies - Global, Regional, Network and Organizational Perspective, edited by J. Kopeć and B. Mikuła, 93-103. Cracow: Cracow University of Economics.

— 2019e. 'Three Decades of Management Accounting in Russia: The Evolution of Understanding of Management Accounting Concept.' In 
Proceedings of the 6th International Scientific Conference Contemporary Issues in Business, Management, and Economics Engineering 2019, 353364. Vilnius: Vilnius Gediminas Technical University.

Lukka, K., and S. Modell. 2010. 'Validation in Interpretive Management Accounting Research.' Accounting, Organizations and Society 35 (4): 462-77.

Miles, M. B., A. M. Huberman, and J. Saldaña. 2014. Qualitative Data Analysis: A Methods Sourcebook. 3rd edition. Thousand Oaks: Sage.

Ministerstvo Finansov Rossiyskoy Federatsii. 2000. 'Ob utverzhdenii plana schetov bukhgalterskogo ucheta finansovo-khozyaystvennoi deyatel'nosti organizatsii i instruktsii po yego primeneneniiu.' Ministerstvo Finansov Rossiyskoy Federatsii, Moscow.

Prezident Rossiyskoy Federatsii. 2012. 'Ukaz "O merakh po realizatsii gosudarstvennoy politiki v oblasti obrazovaniya i nauki.” Prezident Rossiyskoy Federatsii, Moscow.

Puffer, S. M., and D. J. McCarthy. 2011. 'Two Decades of Russian Business and Management Research: An Institutional Theory Perspective.' Academy of Management Perspectives 25 (2): 21-36.

Shields, M. D. 1998. 'Management Accounting Practices in Europe: A Perspective from the States.' Management Accounting Research 9 (4): 50113.

Tavory, I., and S. Timmermans. 2014. Abductive Analysis: Theorizing Qualitative Research. Chicago: University of Chicago Press.

Zolotukhina, T. 2015. 'Postroyenie upravlencheskogo ucheta na osnove otchetnosti po MSFO.' https://finotchet.ru/articles/175/

This paper is published under the terms of the Attribution-

NonCommercial-NoDerivatives 4.o International (CC B Y-NC-ND 4.0)

License (http://creativecommons.org/licenses/by-nc-nd/4.o/). 